\title{
Farmakoterapia po Kongresie ESC 2018 w Monachium - na które pytania znamy już odpowiedź?
}

\author{
Pharmacotherapy after ESC Congress 2018 in Munich \\ - which questions have been answered?
}

\author{
Filip Pawliczak, Jarosław D. Kasprzak
}

Katedra i Klinika Kardiologii Uniwersytetu Medycznego w Łodzi

\section{Streszczenie}

W trakcie 5 sesji hot-line Kongresu ESC 2018 w Monachium zaprezentowano wyniki kilku istotnych badań klinicznych. Autorzy wybrali subiektywnie 5 najważniejszych, odpowiadających na kluczowe pytania z zakresu farmakoterapii chorób układu sercowo-naczyniowego.

Słowa kluczowe: farmakoterapia, Kongres ESC 2018, badania kliniczne, leki, ryzyko sercowo-naczyniowe, śmiertelność, bezpieczeństwo, kwas acetylosalicylowy, infekcyjne zapalenie wsierdzia

Folia Cardiologica 2018; 13, 6: 610-613

W trakcie 5 sesji hot-line podczas ostatniego Kongresu Europejskiego Towarzystwa Kardiologicznego zaprezentowano wyniki kilkunastu interesujących badań klinicznych. Biorąc pod uwagę obecny stan wiedzy oraz nurtujące lekarzy praktyków pytania, autorzy postanowili przedstawić 5 - w subiektywnej ocenie najistotniejszych - prac.

Pierwsze 2 sesje hot-line, były zdominowane przez badania dotyczące jednego z najstarszych współcześnie używanych leków - kwasu acetylosalicylowego (ASA, acetylsalicylic acid). Temat ten otworzyła prezentacja (połączona z jednoczasową publikacją w "The Lancet”) wyników badania ARRIVE (Aspirin to Reduce Risk of Initial Vascular Events) [1]. Głównym założeniem badaczy było przeanalizowanie skuteczności oraz bezpieczeństwa ASA w prewencji pierwotnej u osób z umiarkowanym ryzykiem wystąpienia incydentu sercowo-naczyniowego (10-letnie ryzyko zgonu wieńcowego było równe 10-20\%). Do tej pory skuteczność ASA udowodniono jedynie w przypadku prewencji wtórnej. Mimo braku pewnych dowodów na rzecz korzystnego działania profilaktycznego podawania ASA dość często spotykaną praktyką jest włączanie go w prewencji pierwotnej u pacjentów z pośrednim ryzykiem sercowo-naczyniowym. Warto podkreślić, że taka praktyka nie ma jednoznacznego odzwierciedlenia w europejskich wytycznych i jest postępowaniem kontrowersyjnym.

Badanie ARRIVE było wieloośrodkowym, prospektywnym, podwójnie zaślepionym badaniem z randomizacją, w którym grupę badaną stanowiły osoby otrzymujące ASA w dawce 100 mg/dobe, a kontrolną - placebo. Prezentowane badanie przeprowadzone w 501 ośrodkach w 7 krajach objęło łącznie 12546 pacjentów z pośrednim ryzykiem sercowo-naczyniowym, których po randomizacji podzielono na 2 grupy w stosunku niemal 1:1. Mediana obserwacji wynosiła 60 miesięcy. Do badania nie włączano chorych na cukrzycę lub z wysokim ryzykiem krwawienia. Głównym pomiarem w zakresie skuteczności był czas do pierwszego wystąpienia złożonego punktu końcowego pod postacią śmierci z przyczyn sercowo-naczyniowych, zawału 
serca, niestabilnej dławicy piersiowej, udaru lub przemijającego niedokrwienia mózgu. Punkty końcowe w zakresie bezpieczeństwa to wystąpienie incydentów krwotocznych lub innych zdarzeń niepożądanych.

Wyniki badania nie przyniosły oczekiwanego przełomu z racji braku wpływu na skuteczność prewencji. Główny punkt końcowy wystąpił u 269 pacjentów w grupie badanej $(4,29 \%)$ i u 281 w grupie kontrolnej $(4,48 \%)$ - współczynnik ryzyka (HR, hazard ratio) wynosił 0,96; 95-procentowy przedział ufności (Cl, confidence interval) 0,81-1,13; $p=0,6038$. Warto wskazać na wyniki bezpieczeństwa, ponieważ ryzyko krwawień przy stosowaniu ASA wzrosło ponad 2-krotnie: w grupie badanej krwawienia z układu pokarmowego wystąpiły u 61 pacjentów $(0,97 \%)$, a w grupie kontrolnej u 29 (0,46\%) - HR 2,11; 95\% Cl 1,36-3,28; $p=0,0007$. Pozostałe zdarzenia niepożądane wystąpiły z podobną częstością w obu grupach. W trakcie obserwacji odnotowano 321 zgonów (160 w grupie leczonej ASA [2,55\%], 161 w grupie przyjmującej placebo [2,57\%]), czyli zdecydowanie rzadziej niż przewidywano - wydaje się zatem, że stosowane skale przeszacowują ryzyko współcześnie leczonych pacjentów. Ponieważ ryzyko krwawień przy stosowaniu ASA jest stałe, tłumaczy to brak korzyści netto. W związku z tym zarówno badacze, jak i recenzenci zwrócili uwagę, że wyniki badania bardziej odzwierciedlają stosowanie ASA u osób z niskim ryzykiem sercowo-naczyniowym i nie odnoszą się - wbrew założeniom - do grupy pośredniego ryzyka. Terapia ASA potwierdziła znamienne zmniejszenie ryzyka zawału o 45-47\% w podgrupie pacjentów wykazujących dobrą współpracę terapeutyczną (> 60\% przyjętych dawek, 7702 osoby).

Drugim badaniem związanym z zagadnieniem ASA, którego wyniki zaprezentowano i opublikowano w „The New England Journal of Medicine" tego samego dnia, było ASCEND (A Study of Cardiovascular Events iN Diabetes: Characteristics of a randomized trial of aspirin and of omega-3 fatty acid supplementation in 15,480 people with diabetes) [2, 3]. Badanie to zaprojektowano, by u osób z rozpoznaną cukrzycą porównać jednocześnie wpływ zastosowanych w ramach prewencji pierwotnej ASA w dawce $100 \mathrm{mg} /$ dobę i kwasów tłuszczowych omega-3 w dawce $1 \mathrm{~g} /$ dobę. Punkty końcowe badania zdefiniowano następująco: dla skuteczności - pierwszy epizod istotnego niekrwotocznego incydentu sercowo-naczyniowego (zawał serca, udar lub przemijające niedokrwienie mózgu lub zgon z jakiejkolwiek innej naczyniowej przyczyny); dla bezpieczeństwa - epizod istotnego krwawienia (krwotok wewnątrzczaszkowy, krwawienie do gałki ocznej zagrażające utratą wzroku, krwawienie z przewodu pokarmowego lub inne poważne krwawienia wymagające interwencji). Warto podkreślić, że drugorzędowym punktem końcowym dla ASA było występowanie raka jelita grubego.

Badanie ASCEND było prospektywnym, randomizowanym badaniem z zastosowaniem placebo jako komparatora, do którego włączono 15480 pacjentów. Średni czas obserwacji wyniósł 7,4 roku. Wyniki, choć obiecujące, również nie przyniosły ostatecznej odpowiedzi odnośnie do stosowania ASA. Główny punkt końcowy wystąpił o 12\% rzadziej podczas stosowania ASA niż w populacji kontrolnej: 658 (8,5\%) w porównaniu z 743 (9,6\%); $p=0,01$. Jednocześnie u pacjentów poddanych leczeniu ASA o 29\% częściej pojawiały się poważne krwawienia: 314 (4,1\%) w porównaniu z 245 (3,2\%); p = 0,003, ze zdecydowana przewagą krwawień z przewodu pokarmowego i innych pozaczaszkowych lokalizacji. W aspekcie obserwacji onkologicznej nie odnotowano istotnych statystycznie różnic. Wyniki tego badania potwierdzają, że u pacjentów chorych na cukrzycę, lecz bez powikłań sercowo-naczyniowych ASA może wpływać na obniżenie ryzyka ich wystąpienia, jednak korzyściom płynącym z tego działania w zdecydowanej większości przypadków towarzyszy negatywny wzrost ryzyka poważnych krwawień.

W analizie dotyczącej wykorzystania kwasów tłuszczowych omega 3 w prewencji pierwotnej u pacjentów chorych na cukrzycę nie odnotowano żadnej korzyści z takiej strategii w porównaniu z placebo. Podaje to w wątpliwość sens ich stosowania w codziennej praktyce jako suplementu diety. Jednocześnie autorzy podkreślają znaczenie ich wykorzystania jako dodatku leczniczego u pacjentów ze znaczną hipertriglicerydemią.

Kolejna sesja hot-line mimo odmienności tematycznej obfitowała w interesujące badania farmakologiczne, a szczególną uwagę zwróciło ATTR-ACT (The Transthyretin Amyloidosis Cardiomyopathy Clinical Trial). Prezentacje jego wyników (a także publikacja na łamach „The New England Journal of Medicine" zatytułowana Tafamidis Treatment for Patients with Transthyretin Amyloid Cardiomyopathy) [4] poprzedzono wprowadzeniem słuchaczy w tematykę stosunkowo rzadko wspominanej jednostki chorobowej, jaką jest kardiomiopatia na tle amyloidozy z mutacją transtyretyny (genetycznie uwarunkowana choroba spichrzeniowa polegająca na odkładaniu się złogów nieprawidłowo ukształtowanej transtyretyny w miokardium). Schorzenie ujawnia się najczęściej w 6 . dekadzie życia. Autorzy podkreślają, że choroba może występować dość często (u ok. 13\% pacjentów z niewydolnością serca z zachowaną frakcją wyrzutową), a jedną z nieinwazyjnych metod diagnostycznych okazuje się scyntygrafia kośćca. Warte zaznaczenia jest rokowanie - mediana czasu przeżycia od ustalenia rozpoznania waha się między 2,5 a 3,6 roku w zależności od podtypu mutacji.

Wieloośrodkowe, międzynarodowe, równolegle zaprojektowane, przeprowadzone metodą podwójnie ślepej próby randomizowane badanie kliniczne 3 fazy ATTR-ACT wykorzystywało placebo jako kontrolę wobec zastosowanej strategii leczenia. Głównym celem autorów było zbadanie wpływu tafamidisu na przebieg naturalny schorzenia. Tafamidis jako lek został zarejestrowany do terapii podobnego pod 
względem patomechanizmu schorzenia, jakim jest rodzinna transtyretynowa polineuropatia amyloidowa. Udowodniono, że lek - dzięki wiązaniu się z transtyretyną zamiast tyroksyny - stabilizuje ją w postaci nieszkodliwego tetrameru, co znacząco hamuje rozwój choroby. W zaprezentowanym badaniu postanowiono zweryfikować zasadność podawania tego leku chorym na postać kardiomiopatyczną.

Do badania włączono 441 chorych z takim rozpoznaniem. Zaprojektowano 3 subpopulacje w stosunku 2:1:2 przyjmujące, odpowiednio: tafamidis w dawce $80 \mathrm{mg} /$ dobe, tafamidis $-20 \mathrm{mg} /$ dobę oraz placebo przez 30 miesięcy. Głównymi punktami końcowymi były śmiertelność całkowita, a także częstotliwość hospitalizacji związanych ze schorzeniem układu sercowo-naczyniowego. Drugorzędowe punkty końcowe zdefiniowano jako zmianę wyniku testu 6-minutowego marszu po 30 miesiącach względem momentu randomizacji oraz zmianę uzyskanego wyniku w kwestionariuszu Kansas City Cardiomyopathy Questionnaire-Overall Summary (KCCQ-OS).

Wyniki badania wydają się obiecujące - w badanej grupie (łącznie $80 \mathrm{mg}+20 \mathrm{mg}$ ) liczba zgonów ze wszystkich przyczyn okazała się znacząco niższa niż w grupie przyjmującej placebo: 29,5\% w porównaniu z 42,9\% HR 0,70; 95\% Cl 0,56-0,96 ( $p<0,001$ ). Częstość hospitalizacji odnotowana w grupie badanej również była niższa o 32\% ( $p<0,001$ ). Grupa leczona tafamidisem uzyskiwała lepsze wyniki w kwestionariuszu jakości życia oraz $w$ testach 6-minutowego marszu (dla obu analiz $p<0,001$ ). Co istotne, autorzy zaznaczają, że zarówno liczba, jak i rodzaj działań niepożądanych w obu grupach utrzymywały się na podobnym poziomie.

Podczas następnych sesji hot-line przedstawiono kolejne znakomite badania. Na pierwszej z nich zaprezentowano między innymi wyniki badania FREED (Febuxostat for Cerebral and CaRdiorenovascular Events PrEvEntion StuDy) [5]. Zaprojektowano je jako wieloośrodkowe, prospektywne, randomizowane badanie typu open-label z zaślepionym punktem końcowym i dwoma równoległymi grupami, aby przebadać możliwości febuksostatu (selektywnego inhibitora oksydazy ksantynowej), zmniejszającego stężenie kwasu moczowego we krwi, w aspekcie prewencji incydentów mózgowych, sercowo-naczyniowych i nerkowych w porównaniu ze standardową terapią.

Do badania włączono 1070 pacjentów w wieku 65 lat i powyżej z rozpoznaną hiperurykemią (stężenie kwasu moczowego w surowicy 7,0-9,0 mg/dl). Obserwacja trwała 36 miesięcy. W badanej grupie znalazło się 537 pacjentów, którzy przyjmowali zwiększane dawki febuksostatu (10-40 mg/d.). W grupie kontrolnej allopurinol w dawce $100 \mathrm{mg}$ podawano tylko tym osobom, u których wykryto istotnie podwyższone stężenie kwasu moczowego w surowicy. W obu grupach unikano obniżania stężenia kwasu moczowego poniżej 2,0 mg/dl. U wszystkich pacjentów ryzyko sercowo-naczyniowe było podwyższone w zakresie kontroli znanych czynników ryzyka. Główny złożony punkt końcowy zdefiniowano jako wystąpienie mózgowego, sercowo-naczyniowego lub nerkowego incydentu lub nowej choroby i zgodnu z jakiejkolwiek przyczyny.

Febuksostat wyraźnie obniżył stężenie kwasu moczowego do średniej wartości 4,5 mg/dl w porównaniu z grupą bez tego leku $(6,76 \mathrm{mg} / \mathrm{dl})$ - efekt był obserwowalny po około 8-12 tygodniach terapii. W aspekcie skuteczności leku w prewencji wystąpienia złożonego punktu końcowego wyniki są obiecujące: w grupie przyjmującej lek wystąpił on u 23,3\% pacjentów, natomiast w grupie bez leku $-28,7 \%$. Odnotowano zatem o 25\% niższe ryzyko wystąpienia założonego punktu końcowego w grupie przyjmującej badaną substancje (HR 0,75; 95\% Cl 0,592-0,950; $p=0,017$ ), głównie dzięki zmniejszeniu ryzyka wystąpienia niewydolności nerek - grupa badana (16,2\%) w porównaniu z grupą kontrolną (20,5\%) (HR 0,745, 95\% Cl 0,562-0,987; $\mathrm{p}=0,041)$. W badaniu nie stwierdzono jednak istotnych statystycznie różnic w zakresie występowania zgonów z jakiejkolwiek przyczyny, ryzyka wystąpienia incydentu mózgowo-naczyniowego lub choroby wieńcowej. Było to małe badanie i w kontekście wcześniejszej próby CARES (Cardiovascular Safety of Febuxostat and Allopurinol in Participants With Gout and Cardiovascular Comorbidities; obserwowano w nim zwiększenie ryzyka zgonu u leczonych febuksostatem $v$. allopurinolem) febuksostat wydaje się nie wykazywać ochrony przez powikłaniami krążeniowymi. Nie można z całą pewnością traktować go jako zachęty do szerokiego leczenia bezobjawowej hiperurykemii z założeń prewencyjnych - zgodnie ze światowymi wytycznymi obniżanie kwasu moczowego powinno być zarezerwowane do leczenia objawowej dny moczanowej.

Podczas ostatniej sesji hot-line przedstawiono jedno z najciekawszych z perspektywy klinicysty badań zaprezentowanych podczas tegorocznego Kongresu ESC - POET (Partial Oral versus Intravenous Antibiotic Treatment of Endocarditis). Jednocześnie zostało ono opublikowane w „The New England Journal of Medicine” [6]. Cytowane badanie miało wyjaśnić, czy istnieje możliwość przyjęcia mniej rygorystycznej strategii leczenia lewostronnego infekcyjnego wsierdzia niż zalecana w wytycznych 6-tygodniowa antybiotykoterapia dożylna w warunkach szpitalnych. Badanie zaprojektowano tak, by ocenić skuteczność i bezpieczeństwo przejścia z terapii dożylnej na doustną po 2 tygodniach standardowego leczenia służącego ustabilizowaniu stanu klinicznego chorych.

Badanie POET było duńskim, wieloośrodkowym, randomizowanym, prospektywnym badaniem o typie równoważności, do którego włączono 400 chorych na lewostronne infekcyjne zapalenie wsierdzia w stabilnym stanie hemodynamicznym. Wyselekcjonowani chorzy mieli rozpoznanie ustalone na podstawie wyniku posiewów krwi, z których wyhodowano metycylinowrażliwe paciorkowce, enterokoki lub gronkowce. U wszystkich pacjentów zastosowano 
antybiotykoterapię dożylną przez co najmniej $10 \mathrm{dni}$. Chorych zrandomizowano do 2 grup: leczonych ciągle dożyInie (199 osób) i leczonych dalej doustnie (201 osób). Jeśli istniała taka możliwość, badani po wdrożeniu leczenia doustnego zostali wypisywani i kontrolowani jako pacjenci ambulatoryjni. Głównym punktem końcowym były: śmiertelność całkowita, nieplanowana operacja kardiochirurgiczna, incydenty zakrzepowo-zatorowe lub nawrót bakteriemii pierwotnym patogenem od czasu randomizacji do 6 miesięcy od zakończenia farmakoterapii. Istotne wydają się rodzaj zastosowanych antybiotyków (dobór na podstawie własności farmakokinetycznych) oraz dokładna ocena echokardiograficzna (również przezprzełykową) potwierdzająca brak konieczności stosowania dalszego intensywnego leczenia drogą parenteralną przed ewentualnym włączeniem leczenia doustnego. Nie bez znaczenia była także znacznie częstsza kontrola pacjentów ambulatoryjnych niż w warunkach rzeczywistych.
Mimo zastrzeżeń, na które zwrócili także uwagę recenzenci, wyniki prezentowanego badania nagrodzono gromkimi brawami, ponieważ wydają się niezwykle optymistyczne. Mediana pierwotnego leczenia dożylnego wynosiła 19 dni w grupie leczonej standardowo i 17 dni w grupie leczonej docelowo doustnie $(p=0,48)$. Główny złożony punkt końcowy wystąpił u $24(12,1 \%)$ chorych w grupie poddanej leczeniu dożylnemu oraz u 18 (9,0\%) pacjentów leczonych zgodnie z protokołem badania; różnica między grupami wyniosła 3,1 punktu procentowego, 95\% Cl -3,4-9,6; $p=0,40$, co odpowiada spełnieniu kryterium równoważności. Strategia leczenia doustnego wydaje się zatem rozwiązaniem nie gorszym niż zalecane w wytycznych europejskich i amerykańskich standardowe długotrwałe leczenie dożylne. Dane te są zachęcające i otwierają drogę do dalszego zgłębiania możliwości mniej restrykcyjnego leczenia chorych z łagodnym przebiegiem infekcyjnego zapalenia wsierdzia.

\section{Abstract}

During 5 hot-line sessions at ESC Congres 2018 in Munich several significant clinical trials' results were published. Authors selected top five trials answering the most important questions in pharmacotherapy of cardiovascular diseases.

Key words: pharmacotherapy, clinical trials, ESC Congress 2018, drugs, cardiovascular risk, mortality, safety, acetylsalicylic acid, infective endocarditis

Folia Cardiologica 2018; 13, 6: 610-613

\section{Piśmiennictwo}

1. Gaziano JM, Brotons C, Coppolecchia R, et al. Use of aspirin to reduce risk of initial vascular events in patients at moderate risk of cardiovascular disease (ARRIVE): a randomised, double-blind, placebo-controlled trial. The Lancet. 2018; 392(10152): 1036-1046, doi: 10.1016/s0140-6736(18)31924-x.

2. Bowman L, Mafham M, Wallendszus K, et al. ASCEND Study Collaborative Group. Effects of aspirin for primary prevention in persons with diabetes mellitus. N Engl J Med. 2018; 379(16): 1529-1539, doi: 10.1056/NEJMoa1804988, indexed in Pubmed: 30146931.

3. Bowman L, Mafham M, Wallendszus K, et al. ASCEND Study Collaborative Group. Effects of $n-3$ fatty acid supplements indiabetes mellitus. N Engl J Med. 2018; 379(16): 1540-1550, doi: 10.1056/ /NEJMoa1804989, indexed in Pubmed: 30146932.
4. Maurer M, Schwartz J, Gundapaneni B, et al. Tafamidis treatment for patients with transthyretin amyloid cardiomyopathy. N Eng J Med. 2018; 379(11): 1007-1016, doi: 10.1056/nejmoa1805689.

5. Kojima S, Matsui K, Ogawa H, et al. Febuxostat for Cerebral and Cardiorenovascular Events Prevention Study (FREED) investigators. Rationale, design, and baseline characteristics of a study to evaluate the effect of febuxostat in preventing cerebral, cardiovascular, and renal events in patients with hyperuricemia. J Cardiol. 2017; 69(1): 169-175, doi: 10.1016/j.jjcc.2016.02.015, indexed in Pubmed: 27005768.

6. Iversen K, Ihlemann N, Gill SU, et al. Partial oral versus intravenous antibiotic treatment of endocarditis. N Engl J Med. 2019; 380(5): 415-424, doi: 10.1056/NEJMoa1808312, indexed in Pubmed: 30152252. 